\title{
Measuring universal health coverage to ensure continuing care for older people: a scoping review with specific implications for the Iranian context
}

Seyede Sedighe Hosseini Jebeli, ${ }^{1}$ Aziz Rezapour, ${ }^{2}$ Megumi Rosenberg ${ }^{3}$ and Maziar Moradi-Lakeh ${ }^{4}$

${ }^{1}$ Department of Health Economics; ${ }^{2}$ Health Management and Economics Research Centre, School of Health Management and Information Sciences; ${ }^{4}$ Department of Community Medicine, Preventive Medicine and Public Health Research Centre, Iran University of Medical Sciences, Tehran, Islamic Republic of Iran (Correspondence to: Aziz Rezapour: rezapour.a@iums.ac.ir). ${ }^{3}$ World Health Organization Centre for Health Development, World Health Organization, Kobe, Japan.

\begin{abstract}
Background: To measure progress towards universal health coverage (UHC) in the context of ageing, it is necessary to develop suitable monitoring frameworks. The global UHC monitoring framework is focused on priorities for younger populations and does not adequately address issues relevant to ageing populations.

Aims: This study aims to propose a framework to measure UHC in a way that is relevant to health systems responding to population ageing.

Methods: Based on a search strategy focusing on measures of UHC in relation to older people's care, we searched electronic databases and screened the records to qualitatively analyse the data. We also conducted 2 rounds of expert panel consultations to discuss the findings and examine the feasibility of the recommended indicators using the case of the Islamic Republic of Iran as an example.

Results: We identified main themes and classified core indicators under each theme. Besides 25 indicators for quality of care, there were 22 indicators for financial protection. Ten indicators were retrieved measuring coverage and access to long-term care. Some indicators were excluded owing to limited data availability or absence of related programmes and some alternate indicators were proposed.

Conclusions: We identified several indicators which could be used to measure progress toward UHC in the context of population ageing. However, not all of these indicators are feasible in context of low- and middle-income countries. This study could offer useful general guidance on how to define the exact set of measures in a specific country context.

Keywords: population ageing, long-term care, monitoring frameworks, Iran

Citation: Hosseini-Jebeli SS; Rezapour A; Rosenberg M; Moradi-Lakeh M. Measuring universal health coverage to ensure continuing care for older people: a scoping review with specific implications for the Iranian context. East Mediterr Health J. 2021;27(8):806-817. https://doi.org/10.26719/emhj.21.040

Received: 04/07/20; accepted: 20/12/20

Copyright (C) World Health Organization (WHO) 2021. Open Access. Some rights reserved. This work is available under the CC BY-NC-SA 3.0 IGO license (https://creativecommons.org/licenses/by-nc-sa/3.o/igo).
\end{abstract}

\section{Introduction}

Universal health coverage (UHC) has been defined as the desired outcome of health system performance whereby all people who need health services receive them, without financial hardship. There are 2 interrelated components to UHC: the full spectrum of good-quality, essential health services according to need, and protection from financial hardship (1).

On the journey towards UHC, significant efforts have been made to target specific vulnerable populations, including the poor, women, and children. However, older adults have been often overlooked (2).

Population ageing is a public health concern in both developed and developing countries which dramatically increase the proportion and number of people needing long-term care in countries at all levels of development (3). From 2015 to 2050, the proportion of the world's population aged 60 and over will nearly double, with profound consequences for health care systems (4).
A transformation is needed in the way that health systems are designed in order to ensure affordable access to integrated services that are centred on the needs and rights of older people. In most care contexts, this will require fundamental changes in the way care is organized, funded, and delivered across health and social sectors (5).

With increasing demand for more and different kinds of services, it is imperative to shift resources towards primary care for the preventative and comprehensive care of people with chronic conditions, and establishing linkages with community support (6) as well as allocating the resources efficiently within the primary care sector to meet the healthcare needs of older population. Ensuring an appropriate combination of settings for long-term care that includes both formal and informal care is crucial for this goal. The impact of increases in the older population with disabilities will fall predominantly on the long-term care sector rather than the acute health sector (7). It is noteworthy that providing this segment of population 
with essential long-term care services in terms of health promotion and social care could help them live independently and stay productive for a longer period of time which in turn might has a positive impact on the overall social and economic development. Moreover, to "ensure healthy lives and promote wellbeing for all, at all ages, as stated in the SDGs, health policies will need to be realigned significantly to meet the healthcare needs of older population. The WHO global strategy and action plan on ageing suggests that implementing comprehensive systems of long-term care could accelerate improving UHC for older persons in low- and middle-income countries (LMICs) (8).

The most comprehensive global UHC monitoring framework was published by WHO in 2017 (9); this framework is mostly dominated by maternal and child health and does not cover healthy ageing or the health system capacities and access needed for the care of older persons.

Population ageing has a great impact on achieving UHC. Without considering the needs of older people in terms of social and health services in a country's agenda, achieving UHC is impossible. To evaluate related policies and monitor the progress towards UHC in the context of population ageing, it is necessary to develop suitable frameworks which include measures to assess actions aimed at covering the needs of older people.

Because of the knowledge gap which exists on UHC monitoring approaches and frameworks in the context of population ageing, and regarding the necessity of adapting new health policies to meet the needs of ageing populations, this study aims to review the existing literature on older person's care and UHC measuring frameworks in order to propose a new framework to measure UHC progress in a way that is more relevant to health systems responding to population ageing.

\section{Methods}

\section{Design}

We followed the methodology of Arksey and O'Malley (10) to conduct this scoping review in order to identify and classify themes and indicators to be proposed for monitoring health system responses to population ageing in LMICs to achieve UHC.

\section{Eligibility criteria}

We included all relevant studies at any stage of development, evaluation, or implementation of metrics or measurement frameworks. Any type of study design was included in this review, and we did not filter for date or language of the publications.

We excluded studies which solely focused on concepts and did not provide metrics or measurement frameworks. We also excluded news articles, abstracts, and those studies for which full texts were not available.

\section{Search strategy and information sources}

We searched the following databases to identify relevant studies: Scopus, ISI Web of Knowledge, PubMed, Ovid (including Cochrane Database of Systematic Reviews), and Science Direct.

An electronic search strategy was developed using $\mathrm{MeSH}$ (medical subject headings) terms in consultation with our research team and experts including an experienced research librarian. The search strategy was revised during the review based on the knowledge gathered.

\begin{tabular}{|c|c|}
\hline Set & Strategy \\
\hline 1 & $\begin{array}{l}\text { Search (("Universal healthcare coverage"[Title/Abstract]) OR "Universal health care coverage"[Title/Abstract]) OR "Universal health } \\
\text { coverage"[Title/Abstract]) OR "UHC"[Title/Abstract] }\end{array}$ \\
\hline 2 & $\begin{array}{l}\text { Search ((((("elderly care"[Title/Abstract]) OR "Ageing care"[Title/Abstract]) OR "long-term care"[Title/Abstract]) OR "Integrated } \\
\text { care"[Title/Abstract]) OR "person centred care"[Title/Abstract]) OR "Patient focused care"[Title/Abstract]) OR "elderly friendly } \\
\text { UHC"[Title/Abstract] }\end{array}$ \\
\hline 3 & $\begin{array}{l}\text { Search (("financial protection"[Title/Abstract]) OR "long-term care insurance"[Title/Abstract]) OR "affordability"[Title/Abstract]) OR } \\
\text { "catastrophic costs"[Title/Abstract] }\end{array}$ \\
\hline 4 & Search ("Essential service"[Title/Abstract]) OR "benefit package"[Title/Abstract] \\
\hline 5 & $\begin{array}{l}\text { Search ((("indicator"[Title/Abstract]) OR "measuring"[Title/Abstract]) OR "measuring indicator"[Title/Abstract]) OR } \\
\text { "Monitoring"[Title/Abstract]) OR "measuring framework"[Title/Abstract] }\end{array}$ \\
\hline 6 & 1 AND 2 AND 3 AND 4 AND 5 \\
\hline 7 & 1 AND 2 \\
\hline 8 & 1 AND 5 \\
\hline 9 & 5 AND 2 \\
\hline 10 & 1 AND 4 \\
\hline 11 & 1 AND 3 \\
\hline 12 & 3 AND 2 \\
\hline 13 & 4 AND 2 \\
\hline
\end{tabular}


The first search strategy was more general in order to include the existing UHC measurement frameworks and retrieve as many relevant documents as possible (Table 1). The second search strategy was more specifically focused on the targets of UHC, including quality, equity, service coverage/access, and financial protection (Table 2).

We used hand searching to check all reference lists of included studies to identify additional studies of relevance. We also conducted a targeted search of the grey literature in international organizations' websites and related health or scientific organizations, including the WHO, World Bank, Organisation for Economic Cooperation and Development (OECD), United Nations Development Programme (UNDP), United Nation Children's Fund (UNICEF), UHC2030, and the European Union.

\section{Data collection and analysis}

We used a reference management system (EndNote X8) to manage electronic searches and remove duplicates. The review process comprised 2 levels of screening: a title and abstract review and a full-text review.

All the titles and abstracts were screened by 2 reviewers. Any articles that were identified as relevant by either or both of the reviewers were included for the second step. Full-text articles were then retrieved for articles that met the review criteria or when information in the title and abstract was insufficient to determine eligibility. In the second step, the 2 investigators assessed the full-text articles to determine if they met the inclusion criteria. Any disagreement about study eligibility at the full-text review stage was resolved through discussion with a third investigator until full consensus was obtained.

\section{Data extraction and analysis}

Based on our research objectives, the best choice for analysing data was an informing review, which uses evidence from qualitative research to help define and refine the question and provides descriptive/mapping analysis with limited synthesis.

A standardized data extraction form was developed by the review team. Data abstraction was conducted by
2 of the authors (SHJ and AR) independently extracting data from all included studies. To ensure accurate data collection, each reviewer's abstracted data was compared, and any discrepancies were discussed to reach a final decision.

\section{Expert panel consultation}

As recommended by Arksey and O'Malley (10), we conducted a panel consultation to review the results. The first panel was focused on quality assurance in long-term care of older persons. In the second panel, we focused on the financial/social protection mechanisms and coverage of services for long-term care. In each panel, the facilitator explained about the confidentiality process, and reminded the panel that the session would be audio recorded and that their participation would be acknowledged in the final report.

\section{Discussion guides}

We developed discussion guides to cover gaps which we had identified in the literature review and to examine the feasibility of using the retrieved indicators in the context of the Iranian health system. All the guides were prepared in English, and the panels were conducted in Farsi.

\section{Participants}

We first prepared a long list of potential experts and policy-makers and contacted them by phone. After their approval for the dates and time of the panel, an official invitation letter along with a research brief were sent to them. In total, 9 experts participated in the panels in addition to the research team and a qualitative research expert.

\section{Results}

\section{Study retrieval}

Our search retrieved 18437 studies. After removal of duplicates, 13514 titles/abstracts of records were screened; 101 full-text articles were retrieved for further appraisal, of which 24 documents were eligible (Figure 1).

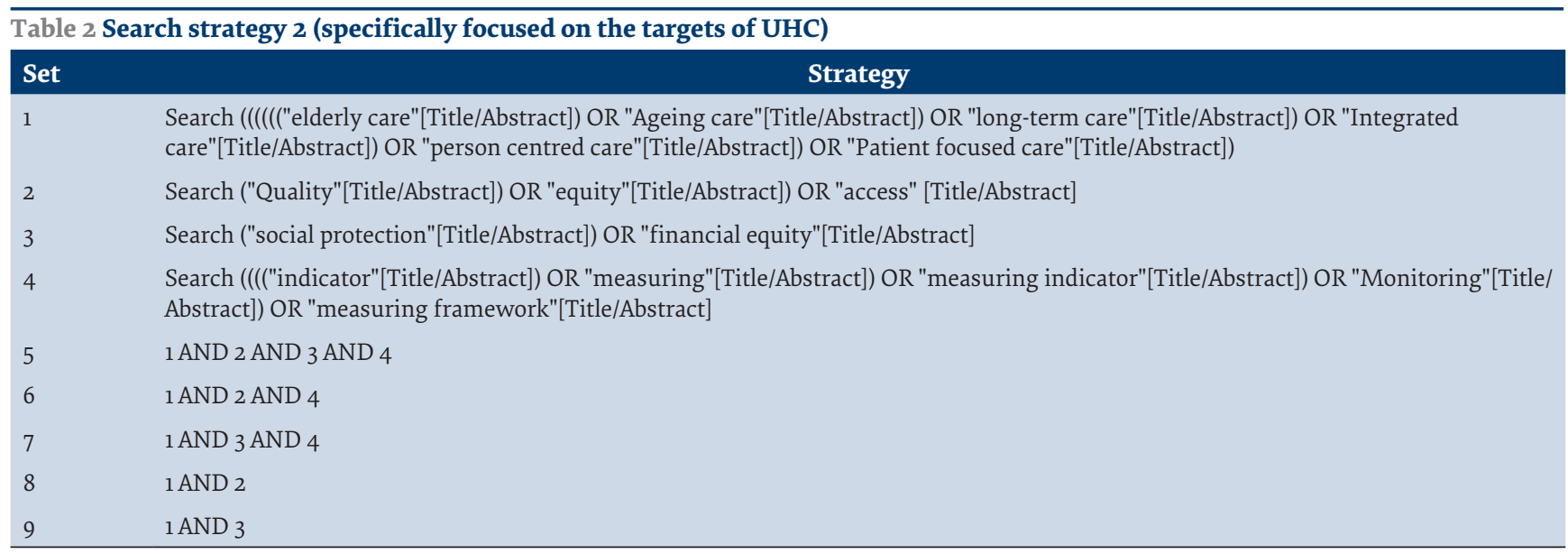




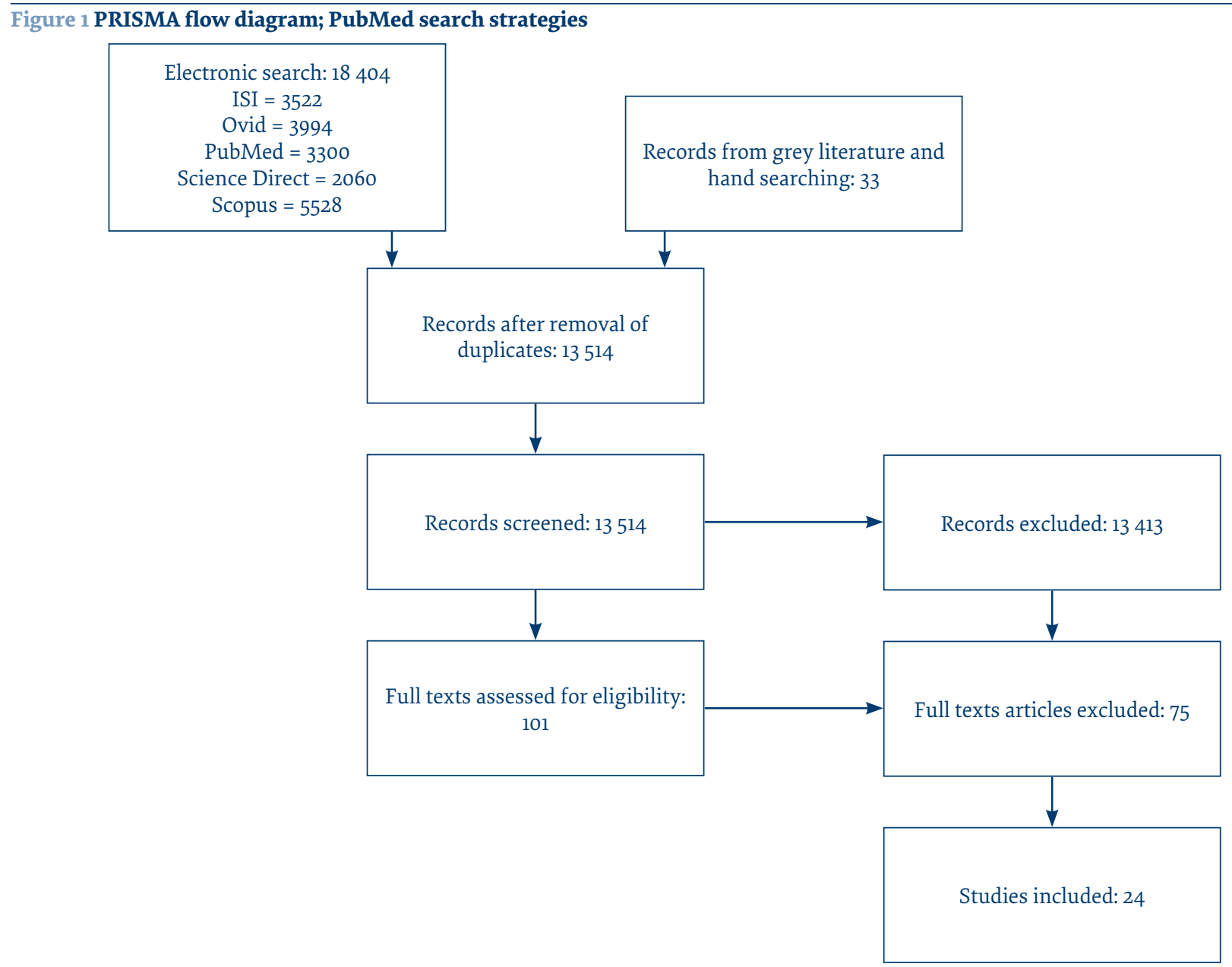

As portrayed in Table 3, we considered 24 documents for this review. By thematic classification, there were 12 documents concerning quality of long-term care and 10 documents on financial and social protection mechanisms. We did not find any specific document measuring coverage or access to long-term care, therefore we included 2 relevant documents containing some single indicators measuring coverage or access level (33,34).

We identified 8 main themes to measure the quality of older person's care in different settings, including longterm care, community care and nursing homes (Table 4). The themes and core indicators were selected based on their frequency in the literature. In total, we identified 25 core indicators to measure the quality of long-term care provided for older people.

Total expenditure, financial protection and social protection were the main themes identified in this study in relation to financial and social arrangements for older person's care that should be measured in the context of UHC (see Table 5). In total we presented 22 indicators in this section.

Table 6 summarizes the themes and indicators that measure the coverage level of and access to long-term care, health centres, and community-based health care.
Based on our review, 10 useful indicators were identified to measure service access.

\section{Results of the panel reviews}

Through the panel reviews, the national background of laws and regulations relating to ageing in the Islamic Republic of Iran were discussed. The most comprehensive and updated document is the National Document of Older Persons announced by the secretary of the National Council of Older Persons in 2017; from this document, the ageing population in Islamic Republic of Iran is defined as the population aged 60 years and over. We used this definition to pursue further discussions on indicators and measurement issues.

\section{Long-term care in the Islamic Republic of Iran}

In the Islamic Republic of Iran, long-term care for older persons in terms of both health and social care is provided through different settings, including nursing homes and day care centres, which are authorized by the National Welfare Organization, community-based care facilitated by Tehran municipality (35) as well as home-based services and home care, which cover the largest proportion of older people who need long-term care. 


\section{Table 3 Study characteristics}

\begin{tabular}{|c|c|c|c|c|c|}
\hline Reference & Theme & $\operatorname{Aim}$ & $\begin{array}{l}\text { Country/ } \\
\text { region }\end{array}$ & Type & $\begin{array}{c}\text { Year } \\
\text { published }\end{array}$ \\
\hline Joling et al. 2018 (11) & Quality & $\begin{array}{l}\text { Provides a comprehensive overview of existing quality } \\
\text { indicators developed or applied to assess the quality of } \\
\text { community care provided to older people }\end{array}$ & - & $\begin{array}{l}\text { Paper- } \\
\text { systematic } \\
\text { review }\end{array}$ & 2018 \\
\hline Chao et al. 2005 (12) & Quality & $\begin{array}{c}\text { Determine residents' perceptions of quality of care in } \\
\text { nursing homes in Taiwan }\end{array}$ & Taiwan & Paper & 2005 \\
\hline Berg et al. 2002 (13) & Quality & $\begin{array}{l}\text { Assess existing quality indicators and to determine which } \\
\text { of them, if any, could be recommended to CMS (Centers for } \\
\text { Medicare and Medicade services) for immediate use }\end{array}$ & USA & Paper & 2002 \\
\hline Grant et al. 1996 (14) & Quality & $\begin{array}{l}\text { Identify indicators of quality of nursing care as perceived } \\
\text { by residents, significant others, and nursing staff in long- } \\
\text { term care facilities }\end{array}$ & Canada & Paper & 1996 \\
\hline Huang et al. 2011 (15) & Quality & $\begin{array}{c}\text { Develop a web based quality monitoring system for long- } \\
\text { term care }\end{array}$ & Taiwan & Paper & 2011 \\
\hline Schols et al. 2014 (16) & Quality & $\begin{array}{l}\text { Describe the regulatory structure and the monitoring of } \\
\text { quality of long-term care in The Netherlands }\end{array}$ & Netherlands & Book chapter & 2014 \\
\hline Kim et al. 2015 (17) & Quality & $\begin{array}{c}\text { Examine the reliability of interRAI Long Term Care } \\
\text { Facilities (interRAI LTCF) and interRAI Home Care } \\
\text { (interRAI HC); provide a comprehensive and integrated } \\
\text { assessment of instruments with common core items in } \\
\text { Korea }\end{array}$ & Korea & Paper & 2015 \\
\hline Hjaltadóttir et al. 2012 (18) & Quality & $\begin{array}{l}\text { Investigate trends in quality of care from 2003-2009 } \\
\text { as reflected in the Minimum Data Set quality indicator } \\
\text { outcome in Icelandic nursing homes }\end{array}$ & Iceland & Paper & 2012 \\
\hline Carpenter et al. 2013 (19) & Quality & $\begin{array}{l}\text { Describe the background of the formation of the interRAI } \\
\text { collaboration and the development, design, distribution, } \\
\text { and potential contribution of the interRAI approach to } \\
\text { assess care and systematic embedding of a quality driven } \\
\text { assessment system in care delivery. } \\
\text { Examine } 3 \text { aspects generally accepted as critical to quality } \\
\text { care: effectiveness and care safety, patient-centredness and } \\
\text { responsiveness, and care co-ordination }\end{array}$ & OECD & $\begin{array}{l}\text { OECD } \\
\text { health policy } \\
\text { studies }\end{array}$ & 2013 \\
\hline Smith $2002(20)$ & Quality & $\begin{array}{l}\text { Examine progress and challenges in the effective } \\
\text { measurement and application of performance indicators to } \\
\text { improve health systems }\end{array}$ & OECD & Book chapter & 2002 \\
\hline Huber et al. 2005 (21) & Quality & $\begin{array}{l}\text { Explore key issues in improving the performance of health } \\
\text { and long-term care systems }\end{array}$ & OECD & Book chapter & 2005 \\
\hline Dandi et al. 2012 (22) & Quality & $\begin{array}{c}\text { Classify quality assurance indicators in different European } \\
\text { countries according to } 3 \text { dimensions: organization type, } \\
\text { quality dimensions and system dimensions }\end{array}$ & Europe & $\begin{array}{l}\text { ENEPRI } \\
\text { research } \\
\text { report }\end{array}$ & 2012 \\
\hline Hsu et al. 2018 (23) & $\begin{array}{l}\text { Financial } \\
\text { protection }\end{array}$ & $\begin{array}{c}\text { Examine the impact of varying } 2 \text { methodological choices } \\
\text { by analysing household expenditure data from a sample of } \\
47 \text { countries }\end{array}$ & 47 countries & Paper & 2011 \\
\hline Campbell et al. 2010 (24) & $\begin{array}{l}\text { Financial } \\
\text { protection }\end{array}$ & $\begin{array}{c}\text { Explore differences between Germany and Japan in } \\
\text { programme goals, eligibility process, scope, size, and } \\
\text { sustainability for possible applications in the United States } \\
\text { of America }\end{array}$ & $\begin{array}{l}\text { Japan and } \\
\text { Germany }\end{array}$ & Paper & 2010 \\
\hline Islam et al. 2017 (25) & $\begin{array}{l}\text { Financial } \\
\text { protection }\end{array}$ & $\begin{array}{l}\text { Investigating progress towards UHC financial risk } \\
\text { indicators and assessed variability of inequalities in } \\
\text { financial risk protection indicators by wealth quintile }\end{array}$ & Bangladesh & Paper & 2017 \\
\hline Saksena et al. 2014 (26) & $\begin{array}{l}\text { Financial } \\
\text { protection }\end{array}$ & Examine existing measures of financial risk protection & - & Paper & 2014 \\
\hline Colombo et al. 2011 (27) & $\begin{array}{l}\text { Financial } \\
\text { protection }\end{array}$ & $\begin{array}{l}\text { Examining key polices and strategies that can help address } \\
\text { future demand for care, and respond to the implications } \\
\text { this will have for long-term care workforce and financing }\end{array}$ & OECD & $\begin{array}{l}\text { OECD } \\
\text { health policy } \\
\text { studies }\end{array}$ & 2011 \\
\hline Lloyd-Sherlock 2002 (28) & $\begin{array}{c}\text { Social } \\
\text { protection }\end{array}$ & $\begin{array}{l}\text { Examine social protection for older people in } 3 \text { middle- } \\
\text { income countries: Argentina, Thailand and South Africa }\end{array}$ & $\begin{array}{l}\text { Argentina, } \\
\text { Thailand, and } \\
\text { South Africa }\end{array}$ & Paper & 2002 \\
\hline $\begin{array}{l}\text { Scheil } \square \text { Adlung et al. } 2013 \\
\text { (29) }\end{array}$ & $\begin{array}{c}\text { Social } \\
\text { protection }\end{array}$ & $\begin{array}{l}\text { Examine the financial impacts on the elderly of private out- } \\
\text { of-pocket expenditure on health care and long-term care in } \\
\text { selected European countries }\end{array}$ & Europe & Policy report & 2013 \\
\hline
\end{tabular}




\begin{tabular}{|c|c|c|c|c|c|}
\hline Reference & Theme & Aim & $\begin{array}{l}\text { Country/ } \\
\text { region }\end{array}$ & Type & $\begin{array}{c}\text { Year } \\
\text { published }\end{array}$ \\
\hline Knaul et al. 2012 (30) & $\begin{array}{c}\text { Social } \\
\text { protection }\end{array}$ & $\begin{array}{c}\text { Analyse the road to universal coverage along } 3 \text { dimensions } \\
\text { of protection: against health risks, for quality assurance } \\
\text { of health care, and against the financial consequences of } \\
\text { disease and injury }\end{array}$ & Mexico & Paper & 2012 \\
\hline Muir 2017 (31) & $\begin{array}{c}\text { Social } \\
\text { protection }\end{array}$ & $\begin{array}{l}\text { Present the first international quantification and } \\
\text { comparison of levels of social protection for long-term care } \\
\text { in } 14 \text { OECD and European Union countries }\end{array}$ & OECD & $\begin{array}{l}\text { Working } \\
\text { paper }\end{array}$ & 2017 \\
\hline Ramírez et al. 2010 (32) & $\begin{array}{c}\text { Social } \\
\text { protection }\end{array}$ & $\begin{array}{l}\text { A Draft Social Policy Note prepared on request by the } \\
\text { Ministry of Social Affairs and Housing - SoZaVo of } \\
\text { Surinam at the outset of a new elected government for the } \\
\text { period 2010- } 2015\end{array}$ & $\begin{array}{l}\text { Suriname } \\
\text { and South } \\
\text { America }\end{array}$ & $\begin{array}{c}\text { Policy } \\
\text { document }\end{array}$ & 2015 \\
\hline OECD 2011 (33) & Coverage & $\begin{array}{l}\text { Present the latest comparable data and trends on key } \\
\text { indicators of health outcomes and health systems across } \\
\text { the } 35 \text { OECD member countries }\end{array}$ & OECD & Report & 2017 \\
\hline Gonzalez et al. 2018 (34) & Coverage & $\begin{array}{l}\text { The overall purpose of this review is improving } \\
\text { development results particularly for most vulnerable and } \\
\text { disadvantaged groups through evidence-based learning }\end{array}$ & Vietnam & Paper & 2014 \\
\hline
\end{tabular}

\begin{tabular}{|c|c|c|c|}
\hline Setting & Subtheme & Core indicators & References \\
\hline \multirow[t]{8}{*}{$\begin{array}{l}\text { Community care } \\
\text { (includes home care \& } \\
\text { primary care) } \\
\text { Nursing homes }\end{array}$} & Cognition/mental health & $\begin{array}{l}\text { - Incidence of depression } \\
\text { - Prevalence of antipsychotic drug use } \\
\text { - Prevalence of dementia }\end{array}$ & $\begin{array}{c}11,12,13,14,17,18, \\
19,21\end{array}$ \\
\hline & Clinical issues & $\begin{array}{l}\text { - Number of falls } \\
\text { - Incidence of nosocomial infections } \\
\text { - Unplanned weight gains or loss } \\
\text { - Prevalence of pressure ulcers } \\
\text { - Incidence of over medication and medication errors. } \\
\text { - Faecal incontinence } \\
\text { - Prevalence of malnutrition } \\
\text { - Residents with poorly managed pain }\end{array}$ & $\begin{array}{l}11,19 \\
17,18,20 \\
13\end{array}$ \\
\hline & Functional performance/status & $\begin{array}{l}\text { - Incidence of use of physical restraint } \\
\text { - Preventable decline of ADL and IADL functioning }\end{array}$ & $17,18,11,13,19,20$ \\
\hline & $\begin{array}{l}\text { Psychosocial aspects: } \\
\text { Social interaction } \\
\text { Social engagement } \\
\text { Social life } \\
\text { Psychosocial function }\end{array}$ & - Social engagement and privacy protection & $11,12,18,19,20$ \\
\hline & $\begin{array}{l}\text { Structure of care: } \\
\text { Nature of facility } \\
\text { Quality of care organization }\end{array}$ & $\begin{array}{l}\text { - } \text { Quality and safety of buildings (e.g. fire hazards, sanitation) } \\
\text { - Amenity of housing environment } \\
\text { - Size of rooms } \\
\text { - Staff ratios; mix of staff qualification }\end{array}$ & $11,14,16,21$ \\
\hline & $\begin{array}{l}\text { Patient-centeredness: } \\
\text { Responsiveness } \\
\text { Caring attitude }\end{array}$ & $\begin{array}{l}\text { - Mechanisms to protect resident rights } \\
\text { - Procedures of resident assessments used for care planning }\end{array}$ & 12,22 \\
\hline & $\begin{array}{l}\text { Continuity and coordination of } \\
\text { care }\end{array}$ & $\begin{array}{l}\text { - Well-functioning transfer and discharge management } \\
\text { - Requirements for clinical records and process of care docu- } \\
\text { mentation } \\
\text { - Maintaining a quality assurance committee } \\
\text { - Well-balanced diet } \\
\text { - Patient safety }\end{array}$ & $11,22,19$ \\
\hline & End of life care & - None identified & 11 \\
\hline
\end{tabular}




\begin{tabular}{|c|c|c|}
\hline Measure/theme & Core indicators & References \\
\hline Expenditure patterns & $\begin{array}{l}\text { Public LTC spending for older persons (\% of health budget) } \\
\text { Public expenditure on health care and LTC (\% of GDP) } \\
\text { Percentage of private LTC expenditure } \\
\text { Percentage of older persons covered by LTC insurance } \\
\text { Population aged 50+ utilizing LTC by per capita household income quintiles (\%) } \\
\text { LTC expenditure (health \& social components) by government and compulsory insurance } \\
\text { schemes (share of GDP) } \\
\text { Government and compulsory insurance spending on LTC (health) by mode of provision } \\
\text { Annual growth rate in expenditure on LTC (health \& social) by government and compulsory } \\
\text { insurance schemes, in real terms }\end{array}$ & $24,27,28,33$ \\
\hline $\begin{array}{l}\text { Financial protection: } \\
\text { OOP payment } \\
\text { Catastrophic expenditure } \\
\text { Impoverishment } \\
\text { Distress financing } \\
\text { (borrowing or selling } \\
\text { assets) }\end{array}$ & $\begin{array}{l}\text { OOP health expenditure by households as a proportion of total income } \\
\text { OOP health expenditure by households as a proportion of disposable income } \\
\text { \% of aged households with OOP expenditure on health care } \\
\text { Health-related OOP expenditure as a percentage of older people's household gross income (by } \\
\text { various items) } \\
\text { Incidence of catastrophic health expenditure: proportion of households in a population who } \\
\text { face catastrophic health expenditure } \\
\text { Mean positive catastrophic overshoot: percentage points by which household spending on } \\
\text { health exceeds the threshold for catastrophic health expenditure } \\
\text { Incidence of impoverishment: proportion of households in a population who fell into poverty } \\
\text { due to health spending } \\
\text { Compensating for the opportunity cost of providing informal care: informal care compensation } \\
\text { rate }\end{array}$ & $26,25,30,31,28$ \\
\hline $\begin{array}{l}\text { Social protection: } \\
\text { Adequate social care } \\
\text { Income support } \\
\text { Independent living } \\
\text { arrangements }\end{array}$ & $\begin{array}{l}\text { Proportional amount of cash transfers to every poor household to meet the equivalent poverty } \\
\text { line } \\
\% \text { of public benefits to the population aged } 65+\text { years } \\
\text { Coverage of family counselling on older person's home care provided through social workers } \\
\text { and health care specialists } \\
\text { Geographic coverage of day care centres for older persons } \\
\text { Counselling and advisory services within day-care institutions specialized for older persons } \\
\text { living independently } \\
\text { Coverage of social housing programmes among older people: \% of independent older persons } \\
\text { benefiting from home improvements or social housing programmes }\end{array}$ & 32,34 \\
\hline
\end{tabular}

LTC = long-term care.

$G D P=$ gross domestic product.

$\mathrm{OOP}=$ out - of - pocket .

\section{Coverage of care}

To discuss the indicator "proportion of people aged 60 years and over receiving long-term care", all types of long-term care in the Islamic Republic of Iran were elaborated in the panel discussions. For nursing homes and day care centres, the data on the numbers of older people are retrievable from the National Welfare Organization, however there are no specific data that can be used to estimate the proportion of older people who receive informal care in their homes by family members.

Estimates for long-term care beds in institutions and their trend can only be retrieved for nursing homes, being the only residential setting providing long-term care for older people.

Proposed indicators include:

- proportion of older persons (aged 60 years and over) who are receiving care in nursing homes at the national and provincial level (by sex),

- proportion of older persons (aged 60 and over) who are receiving care at day-care centres at the national and provincial level (by sex),

- ratio of day-care and nursing homes in each province to population aged 60 years and over,
- number of beds and their trend in nursing homes at the national and provincial level.

\section{Quality of care}

According to the information from the panel, there is no specific organization or office that monitors the quality of long-term care provided to older persons via nursing homes, day-care centres, or home-based services. The main quality themes (including functional performance of older people, structure of care and continuity and coordination of care) which are retrieved from the literature are observed in the regulation of establishing nursing homes and day-care centres in the Islamic Republic of Iran.

\section{Financing of long-term care}

The results from the review on financing issues of longterm care were categorized into 3 main themes: financial protection, social protection mechanisms, and expenditure patterns.

\section{Expenditure pattern}

As indicated above, in the Islamic Republic of Iran longterm care is mostly provided in nursing homes, which are supervised by the National Welfare Organization; there 


\begin{tabular}{|c|c|}
\hline Theme & Indicator \\
\hline Recipients of long-term care & $\begin{array}{l}\text { Proportion of people aged } 65+\text { years receiving long-term care } \\
\text { Share of long-term care recipients, by age } \\
\text { Share of long-term care recipients aged } 65+\text { years receiving care at home }\end{array}$ \\
\hline Informal caregivers & Share of informal caregivers among population aged $50+$ years \\
\hline Long-term care work & $\begin{array}{l}\text { Long-term care workers per } 100 \text { people aged } 65+\text { years } \\
\text { Long-term care workers and population aged } 80+\text { years }\end{array}$ \\
\hline $\begin{array}{l}\text { Long-term care beds in institutions and } \\
\text { hospitals }\end{array}$ & $\begin{array}{l}\text { Long-term care beds in institutions and hospitals } \\
\text { Trends in long-term care beds in institutions and hospitals }\end{array}$ \\
\hline $\begin{array}{l}\text { Community-based and district health } \\
\text { centres }\end{array}$ & $\begin{array}{l}\text { Increase in the number of district health care centres for older people (percentage) } \\
\text { Older persons having access to community-based health care (percentage) }\end{array}$ \\
\hline
\end{tabular}

are no long-term care beds in hospitals. Additionally, the informal care of older persons at home is not recognized.

Based on the System of Health Accounts 1.0 (SHAl) (https://www.who.int/health-accounts/documentation/ SHA1.o/en/), the data on health expenditure is not agespecific and does not provide information on the share of older persons from total health expenditure. The new version of the accounting software, System of Health Accounts 2011 (SHA2011) (https://www.who.int/healthaccounts/documentation/SHA1.o/en/), is in its pilot phase in Tabriz city and provides age-specific expenditure on health. In regard to insurance coverage for long-term care, the panel observed that there is no specific scheme, fund, safety net, or co-payment mechanism specific for long-term care or older person's care.

The proposed indicator is:

- Share of the budget going to nursing homes from the whole government budget.

\section{Financial protection}

Out-of-pocket expenditure on health is reported in national health accounts using the SHAl accounting system, but there is no information on older persons who are spending on health out-of-pocket. The incidence of catastrophic expenditure and impoverishment due to health spending is also observed using information from the National Statistical Centre, but is not specifically retrievable for older people.

\section{Social protection}

Cash transfers to households comprise government subsidies to all Iranian citizens living within the boundaries of the country, including older persons. For poor older persons, there is some financial support from different organizations, including a programme called "Empowering older people" by the Welfare Organization, and the Shahid Rajaei programme, which supports older people in rural areas.

The proposed indicators are:

- proportion of poor older persons who are admitted to nursing homes free of charge;
- proportion of older persons who are registered and supported by the Welfare Organization at the national and provincial level.

\section{Discussion}

\section{Key themes and indicators}

During this study, we identified key UHC measurement themes and indicators which could be applied to measuring UHC in the context of population ageing in LMICs. We also found that healthy ageing indicators are not included among the WHO's 100 core health indicators (36). Despite the growing numbers of older people around the world, these findings show how neglected healthy ageing is in comparison to other areas like maternal and child care or noncommunicable diseases.

\section{Quality of care}

With nations committed to achieving UHC by 2030 , there is a growing acknowledgement that access to services is not enough. Improvement in health care delivery requires a deliberate focus on the quality of health services (37).

While the tendency to measure care performance is shifting from process to (patient-reported) outcome measures, valid outcome indicators for the quality of care for older people are still relatively limited (11). Major outcome indicators, such as falls and fracture rates, prevalence of dementia, and incidence of depression among older persons, could be presented in a UHC measurement framework to monitor the quality of care for older people.

Based on the panel discussions, there is no specific procedure or framework to monitor the quality of care provided in nursing homes and day-care centres in the Islamic Republic of Iran. As the need for long-term care is growing and more families are interested to use such services for the care of their older members, it is necessary to implement official procedures for quality assurance.

\section{Financial protection}

Out-of-pocket costs, catastrophic expenditures, and impoverishing expenses are major indicators for measuring financial protection in varied settings. Key is measuring 
these indicators in different age groups, including households with older members. To calculate catastrophic expenses for older persons, selecting a suitable threshold is important to best represent the financial considerations for this vulnerable group both within and outside of the health sector.

Gaps in European social protection systems for health care and long-term care covering frail older persons frequently result in high levels of out-of-pocket expenditure for the poorest, inequities in access to needed services, and, for some of the most vulnerable, financial ruin (29). Our findings show that in the Islamic Republic of Iran, there is no specific insurance scheme, fund, safety net, or co-payment mechanism to protect older people against the financial risks of health expenditures.

Moreover, older people are a vulnerable group of the population who are mostly retired or are unable to work due to health problems and chronic conditions. At the same time, they require special health care, which imposes costs on the persons or their families. Thus, supporting them in terms of any kind of income support, subsidy, or safety net seems necessary to avoid catastrophic costs.

\section{Coverage level}

Since the need for long-term care services can be broadly interpreted, governments should first focus on developing entitlement standards that determine access to services that are partly or totally publicly funded. As with health care, fair access should be regarded as the first criterion for measuring quality in long-term care (20).
In this study, we focused on long-term care as an essential setting to provide older people with care and services designed for chronic conditions such as dementia and functional disabilities as well as social care.

The long-term care services for older persons in the Islamic Republic of Iran are provided at the home, community and institutional levels. At the home level, there are no data available for the quality of care, which is provided as informal care, indicating the importance of conducting national and provincial surveys to estimate the volume of such care for strategic planning in future years.

\section{Conclusions}

While the population is rapidly ageing around the world, to ensure high quality services are available for older persons as well as equity-oriented financing and delivery mechanisms, the identification of key indicators of healthy ageing and older person's care based on UHC targets should be included in future UHC measurement frameworks. Because most of the indicators have their own challenges in measurement and data requirements, choosing suitable outcome indicators that are globally available, especially in LMICs, is of huge importance.

To best monitor UHC in ageing populations, it is crucial to develop health information systems and plan new national and regional surveys specific to older people's care to gather the necessary data on monitoring indicators. Including the proposed indicators in currently available surveys to be monitored on a regular basis is also another way to gain reliable sources of information.

\section{Acknowledgement}

We would like to express our sincere gratitude to Dr Sarah Louise Barber, Director of the WHO Kobe Centre, and all colleagues at the WHO Kobe Centre who supported us both technically and administratively in this project. We also appreciate the support of Dr Christoph Hamelmann and Mrs Shadrokh Sirous from the WHO Country Office in the Islamic Republic of Iran for providing us with their technical input on the report.

We sincerely appreciate the contributions of the following colleagues who participated in the panel review: Dr Salime Goharinezhad, Dr Mohammad Mehdi Golmakani, Dr Vahid Rashedi, Mr Mohammadreza Asadi, Dr Mohsen Shatti, Dr Mahshid Foroughan, Dr Ali Shojaee, Dr Maryam Ramezanian and Dr Vahid Alipour.

We also acknowledge and appreciate the collaboration of Dr Shandiz Moslehi, a qualitative research expert in this study, and Mr Naser Derakhshani, who supported us with the literature searches.

Funding: This research was supported by the World Health Organization Centre for Health Development (WHO Kobe Centre - WKC: K18022). The full project report is published on the WHO Kobe Centre website as a working paper: https:// extranet.who.int/kobe_centre/en/project-details/Monitoring_UHC_Iran. The working paper will be removed from the link above when the paper is accepted for publication in the EMHJ.

Competing interests: None declared. 


\section{Évaluation de la couverture sanitaire universelle pour assurer des soins continus aux personnes âgées : une étude exploratoire avec des implications spécifiques pour le contexte iranien}

\section{Résumé}

Contexte : Pour mesurer les progrès réalisés sur la voie de la couverture sanitaire universelle dans le contexte du vieillissement, il est nécessaire de mettre au point des cadres de suivi appropriés. Le cadre mondial de suivi de la couverture sanitaire universelle se concentre sur les priorités des populations plus jeunes et n'aborde pas de manière adéquate les problèmes relatifs aux populations vieillissantes.

Objectifs : La présente étude vise à proposer un cadre pour évaluer la couverture sanitaire universelle d'une manière qui soit pertinente pour les systèmes de santé répondant au vieillissement de la population.

Méthodes: Sur la base d'une stratégie de recherche axée sur les mesures de la couverture sanitaire universelle en relation avec les soins aux personnes âgées, nous avons effectué des recherches dans des bases de données électroniques et passé en revue les registres pour analyser qualitativement les données. Nous avons également mené deux cycles de consultations avec un groupe d'experts afin de discuter des résultats et d'examiner la faisabilité des indicateurs recommandés en utilisant le cas de la République islamique d'Iran comme exemple.

Résultats: Nous avons identifié des thèmes principaux et avons classé les indicateurs de base sous chaque thème. Outre les 25 indicateurs pour la qualité des soins, il y avait 22 indicateurs pour la protection financière. Dix indicateurs ont été récupérés pour évaluer la couverture sanitaire universelle et l'accès aux soins de longue durée. Certains indicateurs ont été exclus du fait de la disponibilité limitée des données ou de l'absence de programmes connexes, et d'autres indicateurs ont été proposés.

Conclusions: Nous avons identifié plusieurs indicateurs qui peuvent être utilisés pour mesurer les progrès vers la couverture sanitaire universelle dans le contexte du vieillissement de la population. Cependant, ces indicateurs ne sont pas tous réalisables dans le contexte des pays à revenu faible ou intermédiaire. La présente étude pourrait offrir des orientations générales utiles sur la façon de définir l'ensemble exact de mesures dans le contexte spécifique d'un pays.

$$
\text { قالمياس التغطية الصحة على الصيدة الشاملة لضمان استمر ار تقديم الرعاية للمسنين: استعر اض استكثافي مع الآثار المترتبة }
$$

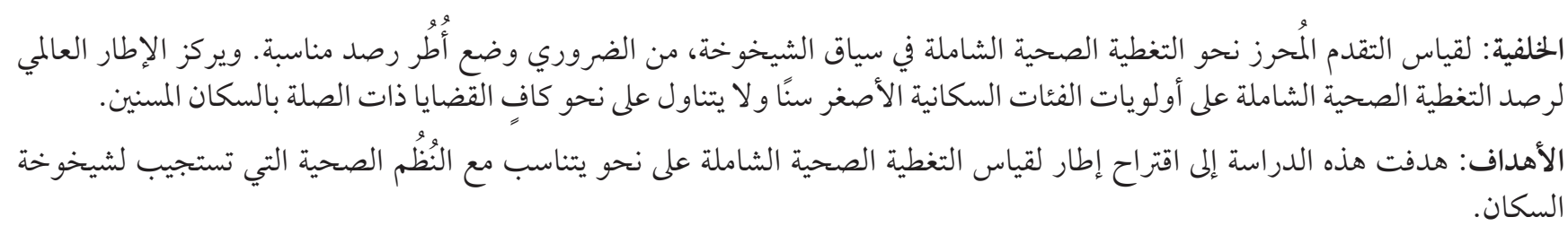

طرق البحث: بناءً على استراتيجية بحثية تركز على تدابير التغطية الصحية الشاملة فيها يتعلق برعاية المسنين، بحثنا في قو اعد البيانات الإلكترونية

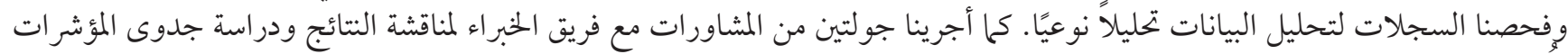

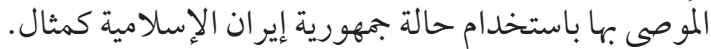

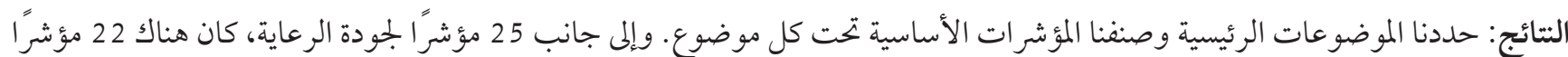

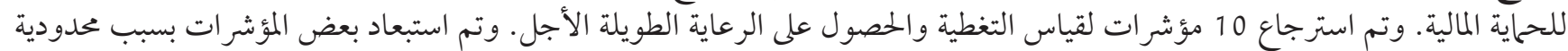

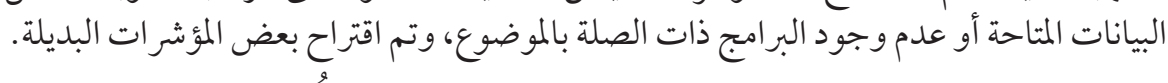

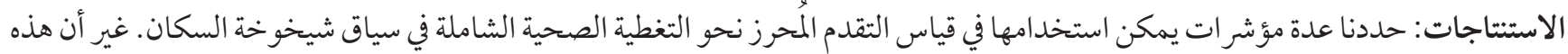

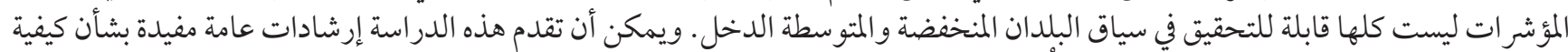

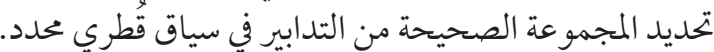




\section{References}

1. Boerma T, Eozenou P, Evans D, Evans T, Kieny M-P, Wagstaff A. Monitoring progress towards universal health coverage at country and global levels. PLoS Med. 2014;11(9):e1001731. doi:10.1371/journal.pmed.1001731

2. Van der Wielen N, Channon AA, Falkingham J. Universal health coverage in the context of population ageing: What determines health insurance enrolment in rural Ghana? BMC public health. 2018;18(1):657. doi:10.1186/s12889-018-5534-2

3. Integrated care for older people: guidelines on community-level interventions to manage declines in intrinsic capacity. Geneva: World Health Organization; 2017.

4. Integrated care for older people: realigning primary health care to respond to population ageing. Geneva: World Health Organization; 2018.

5. Global strategy and action plan on ageing and health. Geneva: World Health Organization; 2017.

6. Barber SL, Rosenberg M. Aging and universal health coverage: implications for the Asia Pacific region. Health Systems \& Reform. 2017;3(3):154-158. doi:10.1080/23288604.2017

7. Rechel B, Doyle Y, Grundy E, McKee M, World Health Organization. How can health systems respond to population ageing. Copenhagen: World Health Organization Regional Office for Europe; 2009.

8. Sadana R, Soucat A, Beard J. Universal health coverage must include older people. Bull World Health Org. 2018;96(1):2. doi:10.2471/BLT.17.204214

9. Tracking universal health coverage: 2017 global monitoring report. Geneva: World Health Organization 2017.

10. Arksey H, O'Malley L. Scoping studies: towards a methodological framework. Int J Soc Res Methodol. 2005;8(1):19-32. doi:10.1080/1364557032000119616

11. Joling KJ, Van Eenoo L, Vetrano DL, Smaardijk VR, Declercq A, Onder G, et al. Quality indicators for community care for older people: a systematic review. PloS One. 2018;13(1):e0190298. doi:10.1371/journal.pone.0190298

12. Chao SY, Roth P. Dimensions of quality in long $\square$ term care facilities in Taiwan. J Adv Nurs. 2005;52(6):609-618. doi:10.1111/j.13652648.2005.03632.x

13. Berg K, Mor V, Morris J, Murphy KM, Moore T, Harris Y. Identification and evaluation of existing nursing homes quality indicators. Health Care Financ Rev. 2002 Summer;23(4):19-36. PMID: 12500468

14. Grant NK, Reimer M, Bannatyne J. Indicators of quality in long-term care facilities. Int J Nurs Stud. 1996 Oct;33(5):469-78. doi:10.1016/0020-7489(96)00012-0

15. Huang E-W, Chen J-C, Liu F-Y, Chiou SF, Duh C, Liou DM, et al. Development of a web-based quality indicators monitoring system for long-term care facilities. Paper presented at the 4th International Conference on Biomedical Engineering and Informatics, 15-17 October 2011. Shanghai; 2011.

16. Schols J, Frijters DH, Kempen RG, Hamers J. Quality monitoring of long-term care for older people in the Netherlands. In: Mor V, Leone T, Maresso A, eds. Regulating long-term care quality: an international comparison. Cambridge: Cambridge University Press; 2014:211.

17. Kim H, Jung YI, Sung M, Lee JY, Yoon JY, Yoon JL. Reliability of the interRAI long term care facilities (LTCF) and interRAI home care (HC). Geriatr Gerontol Int. 2015 Feb;15(2):220-8. doi:10.1111/ggi.12330

18. Hjaltadóttir I, Ekwall AK, Nyberg P, Hallberg IR. Quality of care in Icelandic nursing homes measured with Minimum Data Set quality indicators: retrospective analysis of nursing home data over 7 years. Int J Nurs Stud. 2012 Nov;49(11):1342-53. doi:10.1016/j.ijnurstu.2012.06.004

19. Carpenter I, Hirdes JP. Using interRAI assessment systems to measure and maintain quality of long-term care. In: A good life in old age? OECD and European Union. 2013;17:93-139. doi:10.1787/9789264194564-7-en

20. Smith P. Developing composite indicators for assessing health system efficiency. In: Smith PC, ed. Measuring up: improving health system performance in OECD countries. Paris: OECD; 2002.

21. Huber M, Hennessy P. Long-term care for older people. Paris: OECD Publishing; 2005.

22. Dandi R, Casanova G. Quality assurance indicators of long-term care in European countries. European Network of Economic Policy Research Institutes; 2012 (ENEPRI Research Report No. 110).

23. Hsu J, Flores G, Evans D, Mills A, Hanson K. Measuring financial protection against catastrophic health expenditures: methodological challenges for global monitoring. Int J Equity Health. 2018 May 31;17(1):69. doi:10.1186/s12939-018-0749-5

24. Campbell JC, Ikegami N, Gibson MJ. Lessons from public long-term care insurance in Germany and Japan. Health Aff (Millwood). 2010 Jan-Feb;29(1):87-95. doi:10.1377/hlthaff.2009.0548

25. Islam MR, Rahman MS, Islam Z, Sultana P, Rahman MM. Inequalities in financial risk protection in Bangladesh: an assessment of universal health coverage. Int J Equity Health. 2017 Apr 4;16(1):59. doi:10.1186/s12939-017-0556-4

26. Saksena P, Hsu J, Evans DB. Financial risk protection and universal health coverage: evidence and measurement challenges. PLoS Med. 2014;11(9):e1001701. doi:10.1371/journal.pmed.1001701

27. Colombo F. Help wanted? Providing and paying for long-term care. OECD Health Policy Studies. Paris: OECD Publishing; 2011. 
28. Lloyd-Sherlock P. Formal social protection for older people in developing countries: three different approaches. J Social Policy. 2002;31(4):695-713. doi:10.1017/So047279402006803

29. Scheil $\square$ Adlung X, Bonan J. Gaps in social protection for health care and long $\square$ term care in E urope: Are the elderly faced with financial ruin? Int Soc Security Rev. 2013;66(1):25-48. doi:10.1111/issr.12001

30. Knaul FM, González-Pier E, Gómez-Dantés O, García-Junco D, Arreola-Ornelas H, Barraza-Lloréns M, et al. The quest for universal health coverage: achieving social protection for all in Mexico. Lancet. 2012;380(9849):1259-79. doi:10.1016/So1406736(12)61068-X

31. Muir T. Measuring social protection for long-term care. Paris: OECD; 2017 (Health Working Papers, No. 93).

32. Ramírez M, Angulo R, Walsh S. Assessment report of social policy 2005-2010 Suriname. 2010. Ottawa: ESD International consulting; 2010.

33. Health at a glance 2011. OECD indicators. Paris: OECD Publishing; 2011 (https://www.oecd.org/els/health-systems/49105858.pdf, accessed 12 February 2021).

34. Gonzalez C, Ngoc DD. Equity-focused systematic review of Viet Nam's One Plan (2012-2016). 2014: Viet Nam (file:///C:/Users/ EA/AppData/Local/Temp/Final\%20Report\%20_\%20Equity-focused\%20systematic\%20review\%20of\%20Viet\%20Nam\%C2\%B4S\%20 One\%20Plan\%20(2012-2016)-1.pdf, accessed 12 February 2021).

35. Ghiga I, Cochrane G, Lepetit L, Meads C, Pitchforth E. Understanding community-based social innovations for healthy ageing. Kobe: World Health Orgaization Centre for Health Development; 2018 (https://extranet.who.int/kobe_centre/sites/default/files/ pdf/WHO\%20CBSI\%20Main\%2oReport_FINAL.pdf, accessed 12 February 2021).

36. Global reference list of 100 core health indicators (plus health-related SDGs). Geneva: World Health Organization; 2018.

37. Delivering quality health services: a global imperative for universal health coverage. Geneva: World Health Organization, OECD, and International Bank for Reconstruction and Development/The World Bank, 2018; 2018. 